\title{
Framing Dan Deep Linking Dalam Perspektif Hukum Hak Cipta Di Indonesia
}

\section{Budi Agus Riswandi}

\section{Abstrak}

Framing and deep linking technology on the internet which potentially to do a duplication and announcement raises copy right law problems in Indonesia. These problems raise on the case of duplication and announcement without lisence. Besides that, the problems - also raise on the law enforcement of copy rights infregement related to framing and deep linking technology. Consequently, it is possible to the judges to take different decision upon the case.

\section{Pendahuluan}

Kreasi intelektual pada era informasi yang ditandai dengan kehadiran internet saat ini tidak saja melahirkan kreasi-kreasi intelektual yang dituangkan dalam medium kertas, namun ada juga kreasi-kreasi yang dituangkan dalam medium non kertas (digital).

Konsekuensi dari kreasi yang terdapat pada medium digital, seperti; internet ternyata berdampak juga pada permasalahan hokum. Salah satunya pada hokum hak cipta. Permasalahan ini sangat terasa dikala di dalam medium internet terdapat teknologi yang dikenal dengan framing dan deep linking. Dengan teknologi ini pengguna internet mampu untuk saling menghubungkan antar website. Alhasil, segala informasi yang ada pada website yang dihubungkan tersebutpun ikut terpublikasikan. Akibat publikasi ini, sesungguhnya hal ini telah melahirkan permasalahan hukum hak cipta, terutama hak dari si pemegang hak cipta yang terdapat pada website yang terhubungkan. Tulisan ini akan mengulas atas keberadaan teknologi framing dan deep linking dalam perspektif hukum hak cipta di Indonesia

\section{Sejarah Internet dan Perkembangannya}

Kemampuan komputer untuk membagi data dengan komputer lainnya melalui jaringan yang saling terhubung berdasarkan telepon telah mengarah pada revolusi utama dalam bidang telekomunikasi. Suatu jaringan komputer adalah sebuah jaringan yang mencakup pada komputer utama (server) dan sejumlah stasiun pengendali. Konsep ini dikenal dengan istilah cyberspace. ${ }^{1}$ Istilah

'Suresh T. Viswanathan, The Indian Cyber Laws with Cyber Glossary, Sharat Law House, New Delhi, 2001, him. 4. 
lainnya cyberspace sering disebut juga dengan internet. ${ }^{2}$

Sejarah internet terlahir dikala lembaga riset dalam hal ini The Advanced Research Projects Agency (ARPA) dari Departemen Pertahanan Amerika Serikat mengembangkan jaringan komputer yang dikenal dengan ARPA $\mathrm{NET}^{3}$ Jaringan ini dihubungkan hanya untuk sistem komputer militer dan pemerintahan. Sejarah internet sendiri sangat panjang. Diawali ketika itu, Licklider adalah direktur pertama dari komputer research program DARPA yang dibuka pertama kali pada bulan Oktober 1962. Selama bergabung dengan DARPA Licklider membuktikan kesuksesannya di DARPA bersama dengan Ivan Sutherland, Bob Tylor, dan peniliti MIT Lawrence G. Robert, melakukan penelitian mengenai pentingnya konsep jaringan ini. ${ }^{4}$

Leonard Kleinrock dari MIT menerbitkan tulisan pertamanya tentang teori packet switching pada Julli 1961 dan buku pertamanya dengan subjek yang sama 1964. Kleinrock berusaha meyakinkan Robert secara teoritikal mengenai kemungkinan komunikasi menggunakan packet dibanding menggunakan circuit, di mana hal ini nantinya sebagai pijakan utama dalam pengembangan jaringan komputer. Langkah kunci lainnya adalah membuat komputer ini dapat berkomunikasi antara satu dengan yang lainnya.
Untuk mengeksplorasi ini, tahun 1965 bekerjasama dengan Thomas Merill, Robert berusaha mengkoneksikan TX-2 Komputer di Mass dengan- Q-32 di California dengan menggunakan low speed dial-up telephone line, telah menciptakan wide area computer network yang pertama. ${ }^{5}$

Hasil eksperimen saat itu adalah realisasi bahwa timeshared computer dapat bekerja dengan baik secara bersama-sama, menjalankan program, dan menerima data pada remote mechine, tetapi penggunaan switching dengan sistem telepon tidak mampu untuk menjalankan tugas ini secara maksimal. BulanAgustus 1968; setelah Roberts dan DARPA mendapatkan sponsor, komunitas ini telah menyaring dan memperbaiki keseluruhan struktur dan spesifikasi ARPANET, dan RPQ diperkenalkan oleh DARPA untuk pembuatan salah satu komponen kunci packet switches yang disebut Interface Massage Processor (IMP's). RPQ ini dimenangkan oleh sebuah grup yang diketuai oleh Frank Heart di Bolt Beranek and Newman (BBN). BBN tim ini telah mengerjakan IMP's ini dengan Bob Khan sebagai pemain utamanya di keseluruhan wilayah desain arsitektur ARPANET, tipologi jaringan dan ekonomi ditangani oleh Roberts bekerjasama dengan Howard Frank dan tim kerjanya di Network Analysis Corporation, dan

${ }^{2}$ Cyberspace adalah istilah William Gibson yang dikemukakannya pada tahun 1984 dalam novel fiksinya yang berjudul Necromancer. Kata ini menjelaskan dunia computer secara online dan pendukung masyarakat pengguna computer. Dalam pemikiran yang luas online di sini diindikasikan pada suatu computer yang terhubung dengan lainnya; suatu computer sebagai bagian dari suatu jaringan yang dihubungkan dengan suatu modem. Hal ini dikenal juga dengan internet. Lihat Gareth Grainger, "Freedom of Expression and Regulation of Information in Cyberspace: Issues concerning Potential International Cooperation Principle," UNESCO, The Intermational Dimentions of Cyberspace Law,Ashagate, Singapore, 2000, hlm.72.

${ }^{3}$ Suresh T. Viswanathan, Op.,Cit., hlm. 4.

${ }^{4}$ BudiAgus Riswandi, Hukum dan Internet di Indonesia, UlI Press, Yogyakarta, 2003, him.6. ${ }^{5} \mathrm{lbid}$. 
network measurement systemnya ditangani oleh tim klienrock dan fokusnya pada analisis, desain dan pengukuran, network measurement center-nya di UCLA terpilih menjadi mode pertama ARPANET. ${ }^{6}$

Dalam perkembangannya upayä-upaya tersebut terus dikembangkan. Pada Oktober 1972, Khan mengorganisir sebuah demonstrasi ARPANET yang cukup besar dan sukses di International Computer Comunication Conference (ICCC). Ini adalah tampilan demo publik pertama dari teknologi baru kepada publik. Begitu juga di tahun 1972, aplikasi terpanas electronic mail diperkenalkan. Pada bulan Maret Ray Tomlinson dari BBN membuat software dasar untuk penulisan, pengiriman dan pembaca pesan email, termotivasi dari kebutuhan pengembangan ARPANET atas mekanisme sederhana, cepat dan terkoordinasi antara mereka. $^{7}$

Bulan Juli Roberts memperluas kemampuan sofware ini dengan menciptakan program email pertama yang dapat dipakai untuk mendaftar, menyeleksi, membuat file, forward dan respon atas pesan email. Sejak inilah internet terus berkembang seiring dengan penemuanpenemuan aplikasi barunya. ${ }^{8}$ Gagasan membangun sistem jaringan ini adalah untuk membuat sistem ini aman. Dalam waktu yang sangat cepat jaringan ini dipergunakan juga oleh universitas dan lembaga lainnya untuk sistem jaringan komputer yang mereka miliki.

Pada awal tahun 90-an, setiap orang dengan memiliki komputer, modem dan software internet adalah dapat menghubung dengan internet. Sekarang, internet menghubungkan ratusan ribu jaringan dunia. Jaringan ini mencakup jaringan di universitas, jaringan perusahaan besar dan jaringan pemerintahan. Dengan hal demikian internet berguna untuk mengirim dan menerima electronic mail, software, electronic document dan gambar-gambar di seluruh dunia. Internet secara dramatik telah mengurangi biaya dari komunikasi jarak jauh. ${ }^{9}$

\section{Konsep Dasar Hak Cipta}

Menelusuri hukum hak cipta dan perkembangannya di Indonesia tidak akan dapat dilepaskan dari pengaturan-pengaturan hak cipta sebelum keluarnya UU No. 19 Tahun 2002 tentang Hak Cipta. Awalnya pengaturan hak cipta di Indonesia diatur dalam ketentuan undang-undang warisan kolonial Belanda, yaitu Auteurswet 1912. Kemudian undangundang ini dicabut setelah diberlakukannya UU No. 6 Tahun 1982 tentang Hak Cipta. Pencabutan ini sekaligus menandai ditinggalkannya pengaturan hukum hak cipta yang diwariskan Belanda.

Dalam beberapa tahun kemudian UU No. 6 Tahun 1982 mengalami perubahan dengan ditetapkannya UU No. 7 Tahun 1987 menyangkut beberapa substansi dari undang-undang tersebut. Substansi yang dimaksudkan terdiri di antaranya ruang lingkup hak cipta yang dilindungi dengan menambahkan materi perlindungan hak cipta pada program komputer dan penambahan lama berlakunya hak cipta
${ }^{6} / \mathrm{bid}$.
$7 \mathrm{lbid}$
${ }^{8} \mathrm{Ibid}$.
${ }^{9}$ Suresh T. Viswanathan, Op.,Cit., hlm. 4. 
untuk semua kategori.. Perubahan ini pada hakekatnya sebagai bentuk respon dari hukum hak cipta terhadap perkembangan yang ada di masyarakat. Ada beberapa masalah sebenarnya kenapa UU No. 6 Tahun 1982 perlu. untuk diubah. Sophar Maru Hutagalung mengemukakan empat hal tersebut, yakni: ${ }^{10}$

1. Meningkatnya jumlah pelanggaran hak cipta (seperti pembajak) yang dirasakan telah sampai pada tingkat yang membahayakan;

2. Ancaman pidana terlalu ringan, yang dianggap kurang mampu di dalam menangkal pelanggaran hak cipta;

3. Dirasakan kurangnya koordinasi dan kesamaan pandangan, sikap serta tindakan di antara aparat penegak hukum dalam menghadapi masalah pelanggaran hak cipta;

4. Masih kurangnya tingkat pemahaman mengenai arti dan fungsi hak cipta serta ketentuan-ketentuan undang-undang hak cipta di kalangan masyarakat pada umumnya, dan bahkan di kalangan pencipta pada khususnya.

Pada perkembangannya UU No. 7 Tahun 1987 mengalami perubahan pula dengan diberlakukannya UU No. 12 Tahun 1997. Perubahan ini sebenarnya lebih disebabkan oleh adanya konsekuensi pemerintah Indonesia yang telah meratifikasi persetujuan pembentukan organisasi perdagangan dunia (Agreement Establishing the World Trade Organization) melalui UU No. 7 Tahun 1994. Salah satu aspek yang ada dalam persetujuan tersebut menyangkut masalah Hak atas Kekayaan Intelektual (Agreement on Trade Related Aspects of Intellectual Property RightsTRIPs). Batas akhir proses harmonisasi ketentuan TRIPs ini paling lambat tanggal 1 Januari 1995."

Di samping itu pemerintah Indonesia juga telah meratifikasi beberapa konvensi internasional lainnya di bidang hak cipta, semisal; Keppres No. 18 Tahun 1997 tentang Pengesahan Beme Convention for the Protection of Literary and Artistic Works, Keppres No. 19 Tahun 1997 tentang Pengesahan WIPO Copyrights Treaty. ${ }^{12}$ Keberadaan UU No. 12 Tahun 1997 pun pada akhirnya juga mengalami perubahan dengan diberlakukannya UU №. 19 Tahun 2002 tentang Hak Cipta. Beberapa penyempurnaan UU No. 19 Tahun 2002 terhadap UU No. 12 Tahun 1997, di antaranya:

1. Database merupakan salah satu Ciptaan yang dilindungi;

2. Penggunaan alat apa pun baik melalui kabel maupun tanpa kabel, termasuk media internet, untuk pemutaran produkproduk cakram optik (optical disk) melalui media audio, media audiovisual dan/atau sarana telekomunikasi;

${ }^{10}$ Sophar Maru Hutagalung, "HaK Cipta Kedudukan dan Peranannya di dalam Pembangunan, Edisi Pertama, Jakarta: Akademika Presindo. Dikutip oleh Syamsudin, "Nilai-nilai Karya Cipta dan Problematik Perlindungan Hukumnya," Jumal Hukum No. 16. Vol. 8 Maret 2001, hlm.129.

11 Indonesia dalam mengharmonisasi ketentuan HaKI yang ada pada ketentuan GATTMTO pada kenyataannya batas akhir ini tidak dapat ditepati. Indonesia pada saat itu memberitahu kepada WTO bahwa Indonesia belum dapat mengundangkan RUU Desain Industri. Lihat Zen Umar Purba, "Strategi Pemerintah Melaksanakan Undang-Undang tentang Rahasia Dagang, Desain Industri, dan DTLST," Jumal Hukum Bisnis Vol.13, April 2001, him. 9

${ }^{12}$ Harian Kompas, Senin 7 April 1997. 
3. Penyelesaian sengketa oleh Pengadilan Niaga, arbitrase, atau alternatif penyelesaian sengketa;

4. Penetapan sementara pengadilan untuk mencegah kerugian yang lebih besar bagi pemegang hak;

5. Batas waktu proses perkara perdata di bidang Hak Cipta dan Hak Terkait, baik di Pengadilan Niaga maupun di Mahkamah Agung;

6. Pencantuman hak informasi manajemen elektronik dan sarana kontrol teknologi;

7. Pencantuman mekanisme pengawasan dan perlindungan-terhadap produkproduk yang menggunakan sarana produksi berteknologi tinggi;

8. Ancaman pidana atas pelanggaran Hak Terkait;

9. Ancaman pidana dan denda minimal

10. Ancaman pidana terhadap perbanyakan penggunaan Program Komputer untuk kepentingan komersial secara tidak sah dan melawan hukum.

Secara hakiki hak cipta termasuk hak milik immateriil karena menyangkut ide, gagasan, pemikiran, maupun imajinasi dari seseorang yang dituangkan dalam bentuk karya cipta, seperti buku ilmiah, karangan sastra, maupun karya seni. ${ }^{13}$ Hak cipta itu sendiri muncul secara otomatis pada si pencipta. Pengaturan hak cipta di Indonesia meliputi pada bidang ilmu pengetahuan, seni dan sastra, yang selanjutnya dirinci lagi dalam 14 bagian. Di samping pengaturan itu difokuskan pada 14 bidang tersebut, pengaturan hak cipta di Indonesia juga mengenal beberapa pengecualian yang dianggap bukan pelanggaran hak cipta. Pengecualian-pengecualian itu antara lain:

a. Pengumuman dan perbanyakan dari lembaga negara dan lagu kebangsaan - menurut sifat aslinya;

b. Pengumuman dan perbanyakan dari segala sesuatu yang diumumkan oleh atau atas nama pemerintah, kecuali apabila hak cipta dinyatakan dilindungi, baik dengan peraturan perundangundangan maupun dengan pernyataan pada ciptaan itu sendiri atau ketika cipta itu diumumkan;

_c. - Pengambilan, baik seluruhnya maupun sebagian, berita dari kantor berita, badan penyiar radio atau televisi dan surat kabar dan surat kabar setelah satu kali dua puluh empat jam terhitung dari saat pengumuman pertama berita itu dan sumbernya harus disebutkan secara lengkap.

Dalam Pasal 14 UU No. 19 Tahun 2002 menambahkan beberapa hal yang tidak dianggap sebagai pelanggaran hak cipta, yakni:

a. Penggunaan ciptaan pihak lain untuk keperluan pendidikan, penelitian, penulisan ilmiah, penyusunan laporan, penulisan kritik dan tinjauan suatu masalah dengan ketentuan tidak merugikan kepentingan yang wajar bagi pencipta;

b. Pengambilan ciptaan pihak lain baik seluruhnya maupun sebagian guna keperluan pembelaan di dalam dan di luar pengadilan;

c. Pengambilan ciptaan pihak lain baik

${ }^{13}$ Hanafi, "Tindak Pidana Hak Cipta dan Problematika Penegakan Hukumnya, "Ridwan Khairandy, et.al (ed).Kapita Selekta Hak Kekayaan Intelektuall, Yogyakarta: PSHFH UII, 2000, hlm191. 
seluruhnya maupun sebagian guna keperluan; 1) ceramah yang sematamata untuk tujuan pendidikan dan ilmu pengetahuan; 2) pertunjukan atau pementasan yang tidak dipungut bayaran dengan ketentuan tidak merugikan kepentingan yang wajar bagi penciptanya; 3) perbanyakan suatu ciptaan dalam bidang ilmu, seni, dan sastra dalam huruf braile guna keperluan tuna netra, kecuali jika perbanyakan itu bersifat komersial;

d. Perbanyakan suatu ciptaan selain program komputer, secara terbatas dengan cara atau apapun proses yang serupa oleh perpustakaan umum, lembaga ilmu pengetahuan atau pendidikan dan pusat dokumentasi yang non komersial sematamata untuk keperluan aktivitasnya;

e. Perubahan yang dilakukan atas karya arsitektur seperti ciptaan bangunan berdasarkan pertimbangan pelaksanaan teknis;

f. Perbuatan suatu salinan cadangan suatu program komputer yang dilakukan semata-mata untuk digunakan untuk keperluan sendiri.

Secara normatif dapat disimpulkan bahwa hukum di bidang hak cipta ini telah banyak mengalami pembaharuanpembaharuan. Pembaharuan itu sendiri tidak lain dimaksudkan sebagai upaya antisipatif hukum terhadap perkembangan masyarakat, terutama di bidang hak cipta.

\section{Beberapa Kasus atas Permasalahan Framing dan Deep Linking}

Sebuah layanan internet disajikan dalam bentuk layanan website. Biasanya pihak yang menyediakan website dalam memberikan layanan informasinya tidak hanya dituangkan dalam web pages miliknya, namun dapat pula dilakukan dengan menghubungkannya dengan website lainnya. Dalam kaitan dengan hal ini ada dua istilah yang sangat popular, yakni framing dan deep linking. Framing adalah suatu jendela pada website di mana website lain dapat dilihat. Secara mudah framing dapat juga diartikan dalam konteks suatu website menunjukan halaman dari website lainnya sebagaimana tergambar untuk kepentingan pengunjung (visitors). Dengan adanya framing ini, ternyata telah menimbulkan permasalahan hukum. Hal ini terbukti dengan munculnya kasus pada tahun 1997, yakni antara Washington Post dengan Total News, di mana website milik Total News berisi item-item dari Washington Post. Atas perbuatan ini, maka pengadilan memutuskan hal tersebut sebagai pelanggaran atas hak cipta. Hal ini disimpulkan demikian dikarenakan dengan adanya framing, maka pengunjung memungkinkan downloads dan mengcopynya ke dalam hard disk..$^{14}$

Sementara itu, Margaret Smith Kubiszyn menyatakan bahwa deep linking adalah: "when one site links to a page of another site other than the other site's home page". ${ }^{15}$ Dengan adanya deep linking ini, maka dilihat dari sudut pandang hukum ternyata telah menimbulkan

${ }^{14}$ Douglas J. Wood, "Best Practices forAvoiding Linking and Framing Legal Liability," http://mww.gigalaw.com/ articles/2002-all/wood-2002-06-all.html, diakses tanggal 6 Maret 2006

${ }^{15}$ Margaret Smith Kubiszyn," Emerging Legal Guidance on 'Deep Linking"' http://www.gigalaw.com/articles/2000-all/kubiszyn-2000-05b-all.html, diakses tanggal 6 Maret 2006. 
permasalahan juga. Hal ini sebagaimana dengan kehadiran dari framing. Permasalahan tersebut terlihat dari beberapa kasus di bawah ini: ${ }^{16}$

Pertama, Sebagaimana kasus yang terjadi diAmerika Serikat. Kasus ini diawali dari sebuah perusahaan tiket yang sangat besar melakukan tuntutan terhadap perusahaan tiket lainnya yang telah menghubungkan site untuk halaman penjualan untuk kegiatan khusus pada website tiketmaster.com di bawah home page tiketmasternya. Tersangka dituntut dengan alasan menyamai agen tiket online tersebut. Hal ini dianggap melanggar hak cipta tiketmaster khususnya pada isi informasi yang terdapat pada halaman penjualannya. Meskipun demikian, tersangka sendiri berkeyakinan bahwa tindakannya itu hanya menghubungkan halaman site tiketmaster yang dihubungkan kebagian tiket yang tidak tersedia pada site miliknya. Tersangka berargumentasi bahwa itu tidak dapat dianggap sebagai pelanggaran atas hak cipta tiketmaster karena itu tidak merupakan tindakan perbanyakan atas hak-hak kepemilikan informasi dari tiketmaster. Pengadilan DistrikAmerika Serikat untuk Distrik Pusat California setuju dengan pendapat tersangka yang mana menghubungkan (linking) sendiri tidak merupakan pelanggaran hak cipta.

Kedua, kasus yang terjadi di Amerika Serikat juga yakni ketika ada tuntutan atas ebay oleh sebuah perusahaan mesin pencarian lelang (an auction search engine company). Ebay dituntut dengan alasan melakukan pelanggaran atas ketentuan persaingan tidak sehat (unfair competition). Ebay tidak meminta izin untuk menghubungkan websitenya pada website milik perusahaan mesin pencarian lelang tersebut. Atas tindakannya ini, maka ebay diputuskan oleh hakim Pengadilan Distrik di San Jose California bahwa ebay telah melakukan pelanggaran atas hak kepemilikan untuk meniadakan yang lainnya dari sistem komputernya.

Ketiga, pada kasus yang lain, misalnya dalam kasus StepStone GmbH \& Co.KG v. OfiR Deutschland $\mathrm{GmbH}$ di Jerman. Suatu pengadilan Jerman melarang site pekerjaan Eropa menghubungkan dengan pekerjaan tersedia pada site lainnya sebab dikualifikasikan sebagai deep linking merupakan pelanggaran atas EU Database Directive. Directive melarang suatu perusahaan untuk mendapatkan kembali dan penempatan kembali data yang dikembangkan oleh perusahaan lain tanpa meminta izin kepada pengembang datanya.

\section{Permasalahan Framing dan Linking dan Hukum Hak Cipta}

Hak cipta sebagai hak ekslusif yang melindungi hasil kreasi dalam bidang seni, sastra dan ilmu pengetahuan. Di dalam hak ekslusif terdapat dua hak utama, yakni; hak moral (moral rights) dan hak ekonomi (economic rights). Hak moral adalah hak yang melekat pada diri si pencipta, sedangkan hak ekonomi adalah hak untuk memanfaatkan nilai ekonomi dari sebuah ciptaan yang melekat hak ciptanya.

Hukum hak cipta Indonesia menyatakan bahwa hak cipta timbul secara otomatis. Artinya ketika suatu ciptaan diwujudkan secara nyata dan original, maka hak cipta tersebut

${ }^{16}$ Douglas J. Wood, Op.,Cit., him. 1. 
lahir. Hal ini sejalan dengan ketentuan.Pasal 2 ayat (1) UU No. 19 Tahun 2002 yang menyatakan:

Hak cipta merupakan hak eksklusif bagi pencipta atau pemegang hak cipta untuk mengumumkan atau memperbanyak ciptaannya, yang timbul secara otomatis setelah suatu ciptaan dilahirkan tanpa mengurangi pembatasan menurut peraturan perundang-undangan yang berlaku.

Hak cipta yang dimaksudkan dalam konteks ini, tidak saja meliputi pada ciptaanciptaan yang ada di dunia nyata (the real. world), namun hak cipta ini berlaku juga bagi ciptaan-ciptaan yang terdapat pada medium digital (the virtual world). Pemahaman ini dapat dicermati pada ketentuan Pasal 1 angka (5) UU No. 19 Tahun 2002 yang menyatakan:

Pengumuman adalah pembacaan, penyiaran, pameran, penjualan, pengedaran, atau penyebaran suatu ciptaan dengan menggunakan alat apapun, termasuk media internet atau melakukan dengan cara apapun sehingga suatu ciptaan-dapat dibaca, didengar atau dilihat orang lain.

Dengan demikian, dapat dikemukakan bahwa ciptaan yang ada di dalam internet pun dapat diberikan hak cipta. Permasalahannya saat ini yang timbul bahwa karakteristik dari internet mengenal teknologi framing dan deep linking. Dengan adanya, teknologi ini, maka banyak sekali bermunculkan pemanfaatan hak cipta. Pemanfaatan hak cipta dapat meliputi pada pengumuman dan perbanyakan hak cipta di internet. Adapun hak cipta di internet tersebut di antaranya: ${ }^{17}$

1. Literary Work, yaitu semua bentuk pekerjaan yang didasarkan pada teksteks yang bentuknya mendapatkan hak cipta. Literary work di sini, melingkupi, puisi (poems), buku, artikel, dan hal-hal lainnya yang diekspresikan dalam sejumlah kata dan simbol-simbol lain.

2. Database, yaitu kumpulan data, secara normal adalah dapat hak cipta sebagai kumpulan.

3. Characters, yaitu karakter-karakter fiksi dalam bentuk visual, seperti tokoh Mickey Mouse dan Superman, dalam bentuk literatur, seperti teks cerita Sherlock Holmes, Hardy Boys, atau James Bond.

4. Musical Works, yaitu karya musik yang dapat hak cipta. Perlindungan hak cipta untuk karya musik adalah menjangkau kedua hal; kata-kata dan musiknya.

5. Sound Recording, adalah rekaman suara yang dihasilkan dari rekaman, seperti musik-musik seri, perbincangan,-dan suara lainnya.

6. Photograps dan Still Images, yakni gambar-gambar dan karya grafik yang dapat hak cipta. Meliputi; komik, strips, periklanan, gambar tekhnik, diagram yang dapat hak cipta.

7. Motion Pictures and Other Audiovisual Works, yakni gambar-gambar hidup, video, dan karya-karya audiovisual yang

${ }^{17}$ Muhammad AuliaAdnan, "Intellectual Property Rights in Cyberspace," Jumal Hukum Bisnis Vol. 13April 2001, hlm. 77. Lihat juga pada Thomas J. Smedinghoff, "Copyrights in Digital Information," Dalam Online Law the SPA's Legal Guide to Doing Business on the Internet, Canada: Wesley Publishing Company, lnc, 2000. HIm.140-142. 
dapat hak cipta.

8. Software, adalah perangkat lunak yang dapat hak cipta. Bagaimanapun ketika itu diciptakan, seluruh software di dunia maya dikualifikasi sebagai karya yang dapat hak cipta.

9. Compilation and Derivative Works. Compilation adalah sebuah karya yang dibentuk melalui pengumpulan, pemasangan, pengadaan materi atau data yang kemudian diseleksi, dikoordinasikan atau diatur yang menghasilkan karya sebagai keseluruhan karya originil dari pengarang. Untuk contoh, majalah, katalog. Derivative work adalah sebuah karya yang didasarkan pada satu atau lebih karya, seperti terjemahan, fiksi, versi gambar-gambar hidup.

10. Multimedia works, yakni multi media adalah karya umum yang menggabungkan satu atau dua dari kategori yang ada ke dalam medium tunggal.

Dari sini, maka permasalahan semakin berlanjut tatkala perbanyakan dan pengumuman tersebut tidak lagi memperhatikan pada prinsipprinsip dasar hukum hak cipta. Seperti diketahui, ada beberapa prinsip dasar hukum hak cipta yang harus senantiasa diperhatikan oleh pengguna hak cipta, baik melalui internet ataupun tidak. Prinsip-prinsip dasar hokum hak cipta tersebut mencakup pada: ${ }^{18}$

1. Yang dilindungi hak cipta adalah ide yang telah berwujud dan asli.

Salah satu prinsip yang paling fundamental dari perlindungan hak cipta adalah konsep bahwa hak cipta hanya berkenaan dengan bentuk perwujudan dari suatu ciptaan misalnya buku, sehingga tidak berkenaan atau tidak berurusan dengan substansinya. Dari prinsip dasar ini telah melahirkan dua sub prinsip, yaitu:

Pertama, suatu ciptaan harus mempunyai keaslian (orisinil) untuk dapat menikmati hak-hak yang diberikan undang-undang keaslian, sangat erat hubungannya dengan bentuk perwujudan suatu ciptaan.

Kedua, suatu ciptaan, mempunyai hak cipta jika ciptaan yang bersangkutan diwujudkan dalam bentuk tertulis atau bentuk material yang lain. ini berarti bahwa suatu ide atau suatu pikiran atau suatu gagasan atau cita-cita belum merupakan suatu ciptaan.

2. Hak cipta timbul dengan sendirinya (otomatis).

Suatu hak cipta eksis pada saat seorang pencipta mewujudkan idenya dalam suatu bentuk yang berwujud yang dapat berupa buku. Dengan adanya wujud dari suatu ide, suatu ciptaan lahir. Ciptaan yang dilahirkan dapat diumumkan (to make public/openbaarmaken) dan dapat diumumkan. Suatu ciptaan yang tidak diumumkan, hak ciptanya tetap ada pada pencipta.

3. Suatu ciptaan tidak perlu diumumkan untuk memperoleh hak cipta.

Suatu ciptaan yang diumumkan maupun yang tidak diumumkan (published/unpublished work) kedua-duanya dapat memperoleh hak cipta.

4. Hak cipta suatu ciptaan merupakan

${ }^{18}$ Edy Damian, Hukum Hak Cipta, Alumni, Bandung, 2002, hlm. 99-106. Lihat juga Budi Agus Riswandi dan Syamsudin, Hak Kekayaan Intelektual dan Budaya Hukum, Rajawali:Press, Jakarta, 2004, hlm. 8-10. 
"suatu hak yang diakui hukum (legal right) yang harus dipisahkan dan harus dibedakan dari penguasaan fisik suatu ciptaan.

5. Hak cipta bukan hak mutlak (absolute)

Hak cipta bukan suatu monopoli mutlak melainkan hanya suatu limited monopoly.-Hal: ini dapat terjadi karena hak cipta secara konseptual tidak mengenal konsep monopoli penuh, sehingga mungkin saja seorang pencipta menciptakan suatu ciptaan yang sama dengan ciptaan yang telah tercipta terlebih dahulu.

Oleh karena itu memahami hák cipta yang ada di internet dan prinsip-prinsip dasar hak cipta, maka dapat dikatakan bahwa pemanfaatan hak cipta melalui teknologi framing dan linking akan menjadi permasalahan tatkala teknologi tersebut digunakan untuk memperbanyak dan mengumumkan ciptaan dengan tanpa melalui izin dari pemegang hak ciptanya. Izin di sini, harus dipahami dalam dua konteks; Pertama, izin apabila perbanyakan dan pengumuman dimaksudkan untuk tujuan komersial, maka izin tersebut tidak saja dengan menyebutkan nara sumbernya namun harus disertai dengan membayar sejumlah royalty. Kedua, izin apabila perbanyakan dan pengumuman dimaksudkan untuk tujuan penelitian, pendidikan, dan karya ilmiah, maka izin tersebut cukup dengan menyebutkan nara sumbernya.

Apabila kedua hal ini tidak diperhatikan, maka perbuatan pengguna internet (users) dapat dikatakan sebagai perbuatan melanggar hak cipta. Konsekuensi daripada pelanggaran hak cipta ini, maka seorang pengguna internet (users) dapat diproses baik secara perdata maupun secara pidana. Akan tetapi, berkenaan dengan proses perdata maupun pidana ini, maka kesulitan yang dihadapi terletak pada proses pengadilan itu sendiri. Meskipun, secara normatif perbanyakan dan pengumuman melalui internet dengan menggunakan teknologi framing dan deep linking dengan tidak minta izin dapat dikualifikasi sebagai tindakan pelanggaran, akan tetapi hăl ini tidak menjamin bahwa dalam proses pengadilan akan melahirkan suatu persepsi yang sama. Hal ini diperkuat lagi dengan adanya kebebasan hakim untuk memberikan putusan dengan atau tanpa terikat dengan putusan hakim sebelumnya. Kasus ini terjadi juga di beberapa Negara sebagaimana dikemukakan di atas. Inilah kiranya, suatu permasalahan hokum yang semestinya disikapi oleh para anggota legislatif dan pemerintah dalam kaitannya dengan hukum hak cipta di Indonesia. Bagaimana pun harus diakui bahwa pengaturan yang saat ini ada berhubungan dengan hak cipta di internet masih sangat terlalu sumir. Sehingga, hal ini perlu dipertegas dan diperjelas, sehingga penafsiranpenafsiran hakim yang akan menimbulkan putusan yang berbeda dapat diminimalisir.

\section{Simpulan}

Teknologi framing dan deep linking yang terdapat di internet yang memungkinkan untuk dilakukannya perbanyakan dan pengumuman ciptaan telah menyebabkan munculnya permasalahan hukum hak cipta di Indonesia. Permasalahan tersebut timbul dalam hal perbanyakan dan pengumuman ciptaan yang tidak melalui izin dan penyelesaian hukum hak cipta sendiri atas pelanggaran hak cipta melalui teknologi framing dan deep linking, di mana hakim sangat dimungkinkan untuk melahirkan putusan yang berbeda atas 
masalah ini.

\section{Daftar Pustaka}

Budi Agus Riswandi dan Syamsudin, Hak Kekayaan Intelektual dan Budaya Hukum, Rajawali Press, Jakarta, 2004. Budi Agus Riswandi, Hukum dan Internet di Indonesia, UII Press, Yogyakarta, 2003.

Douglas J. Wood," Best Practices for Avoiding Linking and Framing Legal Liability," http://www.gigalaw.com/articles/2002all/wood-2002-06-all.html, diakses tanggal 6 Maret 2006.

Edy Damian, Hukum Hak Cipta, Alumni, Bandung, 2002.

Gareth Grainger, "Freedom of Expression and Regulation of Information in Cyberspace: Issues concerning Potential International Cooperation Principle," UNESCO, The International Dimentions of Cyberspace Law,Ashagate, Singapore, 2000.

Hanafi, "Tindak Pidana Hak Cipta dan Problematika Penegakan Hukumnya, "Ridwan Khairandy, et.al (ed). Kapita Selekta Hak Kekayaan Intelektual I,
Yogyäkarta: PSH FH UIl, 2000. -Margaret Smith Kubiszyn," Emerging Legal Guidance on 'Deep Linking'" http:// www.gigalaw.com/articles/2000-all/ $\therefore$ kubiszyn-2000-05b-all.html, diakses tanggal 6 Maret 2006.

Muhammad Aulia Adnan, "Intellectual Property Rights in Cyberspace," Jurnal Hukum Bisnis Vol. 13April 2001.

Suresh T. Viswanathan, The Indian Cyber Laws with Cyber Glossary, Sharat Law House, New Delhi, 2001.

Syamsudin, "Nilai-nilai Karya Cipta dan Problematik Perlindungan Hukumnya," Jumal Hukum No. 16. Vol. 8 Maret 2001. Thomas J. Smedinghoff, "Copyrights in Digital Information," Dalam Online Law the SPA's Legal Guide to Doing Business on the internet, Canada: Wesley Publishing Company, Inc, 2000.

Zen Umar Purba, "Strategi Pemerintah Melaksanakan Undang-Undang tentang

- Rahasia Dagang, Desain Industri, dan DTLST," Jurnal Hukum Bisnis Vol.13, April 2001

Kompas, Senin 7 April 1997. 